\title{
ConteXtualising THE DeCISIONS OF THE NATIVE LAND COURT: THE CHATHAM ISLANDS INVESTIGATIONS OF 1870
}

\author{
R P Boast
}

One of the outcomes of the Lost Cases project at the Faculty of Law at Victoria University will be an edition of nineteenth century judgments of the Native Land Court. These decisions have never been reported before. The anticipated date of publication is mid-to late-2011, and the volume will report leading decisions of the Native Land Court, Compensation Court, ${ }^{1}$ and associated bodies from 1865 to 1894. The date of 1894 has been selected as a cut-off for the reason that the Native Land Court Act 1894 established a new appellate body, the Native Appellate Court - today the Maori Appellate Court - which began issuing appellate judgments immediately. Until this point all appeals had been by means of rehearings and no formal appellate structure existed. Future volumes will report decisions of the Native Land Court and Native Appellate Court down to the present day. This article explores the current state of the historiography relating to the Native Land Court, and by reference to the Chatham Islands Investigation of 1870, suggests that a more complex and nuanced approach to the work of the Court is needed. The full texts of the Chatham Islands judgments of 1870 are printed as an Appendix.

* Professor of Law, Victoria University of Wellington. My thanks to Sophie Crichton and Lisa Black for assistance with transcriptions. Those research assistants were financed through the Lost Cases project funded by the New Zealand Law Foundation.

1 The Compensation Court was a special body set up under the New Zealand Settlements Acts to deal with land confiscated from "rebel" Māori under the New Zealand Settlements Act 1863 and other enactments relating to confiscated land. For an introductory survey of the legislation relating to confiscation and to the operations of the Compensation Court see RP Boast, "An Expensive Mistake: Law, Courts and Confiscation on the New Zealand Colonial Frontier" in RP Boast and RS Hill (eds) Raupatu: The Confiscation of Maori Land (Victoria University Press, Wellington, 2009) at 145-168. 


\section{INTRODUCTION}

The Native Land Court is a very important body in New Zealand's legal history. As the Maori Land Court it is still very much in operation, and continues to be a busy institution and important in the Māori world. The Court has jurisdiction over Māori freehold land, an important category of land in New Zealand, especially in the North Island where it covers about 13 per cent of the surface area. In the 19th century the Court was mainly a land titles court, issuing judgments in rem determining title to Māori land blocks, some of which were very substantial. The case studied in this article, for example, the Chatham Islands investigation of title (1870), determined title to the whole of the Chathams - about 240,000 acres. Some of the cases on the mainland related to even larger areas. The Rohe Potae case, decided in 1886, related to an area of 1.6 million acres, and the Tauponuiatia decision (also 1886) to an area about one million acres, including much of Lake Taupo and the volcanic peaks of what is now Tongariro National Park. A Court decision that determined title to 1.6 million acres is obviously a matter of some significance in our legal history. The Native Land Court that heard the Rohe Potae case released a fairly detailed decision explaining the reasons for its determination. Yet this decision has never been reported anywhere and still lies buried in the Court's manuscript records and in the newspapers of the day.

As well as serving as a case study of the Native Land Court in action, the 1870 Chathams decisions are of great intrinsic importance and interest. These decisions have been much written about and were an important issue in the Waitangi Tribunal's Rekohu report of 2001. ${ }^{2}$ They are one of the few occasions on which the Native Land Court dealt with the customary interests of the Moriori people, the indigenous people of the Chatham Islands. The ancestors of the Moriori people probably reached the Chatham Islands from mainland New Zealand and are recognised by anthropologists and archaeologists as constituting a distinct Polynesian culture different in many respects from Māori. ${ }^{3}$ As can be seen from the judgments, Moriori tradition is that the people arrived directly from Hawaiki in a number of canoes which appear to be known only in the

2 Waitangi Tribunal Rekohu: A Report on Moriori and Ngati Mutunga Claims in the Chatham Islands, Wai 64, 2001. I need to disclose that I presented historical evidence on behalf of Ngati Mutunga as an expert witness in this inquiry.

3 See Douglas Sutton "The Chatham Islands" in Nigel Prickett (ed) The First Thousand Years: Regional Perspectives in New Zealand Archaeology (Dunmore Press, Palmerston North, 1982) at 160-178. In this authoritative discussion Sutton sees Moriori culture as having developed in the Chatham Islands, deriving from settlers who belonged to the same Eastern Polynesian stock who colonized and settled mainland New Zealand and from whom Māori culture developed. After circa 1400 AD the islands "became a closed system" because "a climatic deterioration, known as the Little Ice Age, worsened sea conditions and therefore effectively distanced the Chathams even further from New Zealand" (at 167). See also Waitangi Tribunal Rekohu, above $\mathrm{n} 3$ at 20-32. The Tribunal's view, however, that "Moriori are the same people as Māori but, through isolation, they are unique as a Māori tribe" (at 21) although perhaps justifiable legally, overstates the position in terms of history, anthropology and archaeology. 
Chathams. ${ }^{4}$ Living in isolation for centuries in the Chatham Islands Moriori culture evolved in its own highly distinctive ways and developed a commitment to peaceful resolution of disputes that was unique in the Polynesian world. There is no foundation for the common belief that Moriori people are "extinct" and there are many people of Moriori descent alive today. ${ }^{5}$ It should be unnecessary to add that the belief that there was a pre-Māori "Moriori" population in mainland New Zealand has no scientific basis.

\section{INTERPRETING THE NATIVE LAND COURT}

Notwithstanding the fact that its decisions have never been published, there is a large literature on the Native Land Court. On the whole historians have not viewed it favourably. James Belich, reflecting perhaps the historiographical consensus of the time, wrote in Making Peoples (1996) of this "notorious institution", the Native Land Court, "designed to destroy Māori communal land tenure and so facilitate Pakeha land buying and 'detribalise' Māori" - although Belich, never one to accept old shibboleths uncritically, also noted that "the picture of naïve Māori victims succumbing to legal chicanery and the blandishments of cunning land buyers and storekeepers can be overdrawn." ${ }^{6}$ Most historians were, however, aware that the Court evolved in the course of its long history, metamorphosing into the Māori-friendly - and largely Māori-run - institution of the present day. At some point, it is not clear when, the 'bad' 19th century Court somehow turned into the 'good' Maori Land Court of today.

By the time when the Waitangi Tribunal embarked on its first full inquiries into the workings of the Native Land Court and the Native Lands Acts a settled critique of the Court had evolved. First, it was generally accepted that the Native Land Court was set up by the Government by means of the Native Lands Acts with the specific purpose of dispossessing Māori by making Māori land readily alienable to "settlers". As a consequence of this, Māori landlessness, and hence Māori poverty significantly worsened. Some historians went so far as to see the legislation and the Court as a conscious attack or assault on Māori society by the settler regime - an attack which in the long run was all too successful. Secondly, a number of historians claimed that the Court process itself contributed to worsening Māori poverty, health and mortality in the nineteenth century. This

4 On Moriori canoe traditions see Alexander Shand The Moriori People of the Chatham Islands (Memoir of the Polynesian Society, Wellington, 1911) at 100-119.

5 See Waitangi Tribunal Rekohu, above n 2, at 32: "Moriori are clearly in the process of rebuilding, but the culture survives and they are rebuilding from the bottom up".

6 James Belich Making Peoples: A History of the New Zealanders: From Polynesian Settlement to the End of the Nineteenth Century (Allen Land/Penguin Press, Auckland, 1996) at 258-259. For other assessments in general histories see for example Philippa Mein Smith A Concise History of New Zealand (Cambridge University Press, Cambridge, 2005) at 72-73 (Mein Smith describes the Land Court as "worse" than confiscation under the New Zealand Settlements Acts, and states also that the Native Land Court "certainly earned its contemporary title of the 'land-taking court'", although in fact it was the Compensation Court, not the Native Land Court, which earned, and perhaps deserved, that particular sobriquet). 
argument is particularly associated with an important article published as long ago as 1956 by Keith Sorrenson in the Journal of the Polynesian Society. ${ }^{7}$ Thirdly there was a critique of the Court's procedure: for example it was assumed that the Court imposed a narrow and doctrinaire legal straitjacket on Māori custom, which the judges in any case were not capable of understanding. Alan Ward, for example, has written that "[o]ne can indeed marvel at the confidence, or temerity, with which the judges made their decisions and, in effect, codified custom". ${ }^{8}$ And finally, there was a critique that the Native Land Court was not in fact a "court" deserving of the name: it was simply an agency of the executive, merely an arm of the Native Department, its judges entirely lacking in any proper sense of judicial independence.

Added to all of these critiques of the Court there was also a critique of lawyers: all lawyers who practised in the Native Land Court were perceived as simply shysters and crooks. This opinion was probably more founded on stereotypical opinions held about lawyers than on any real understanding of who practised in the Native Land Court and what kind of roles lawyers actually played in the proceedings. Sweeping criticisms of lawyers are nothing new - James Brundage has demonstrated that much of what is said about lawyers in recent times is no different from what was said about canon lawyers in the thirteenth century. ${ }^{9}$ In fact there were no lawyers involved in the Chathams case discussed below and from time to time lawyers were banned from appearing in the Native Land Court by legislation. ${ }^{10}$ Speaking as lawyer, my own feeling is that the Moriori people might have

7 MPK Sorrenson "Land Purchase Methods and their effect on the Maori population, 1865-1901" (1956) 65 Journal of the Polynesian Society 183. There has now been a flood of new research on Māori nineteenthcentury social history for the Waitangi Tribunal inquiries.

8 Alan Ward "Historical Method and Waitangi Tribunal Claims" in Miles Fairburn and Bill Oliver (eds) The Certainty of Doubt: Tributes to Peter Munz (Victoria University Press, Wellington, 1996) 140-156 at 144.

9 See James A Brundage The Medieval Origins of the Legal Profession: Canonists, Civilians, and Courts (University of Chicago Press, Chicago, 2008) 447-487. "Lawyers", as Brundage observes (at 485), "have never been popular".

10 The Native Lands Acts 1873, s 44 stipulated that cases before the Court were to be conducted "without the intervention of any counsel or other agent". In 1878 the ban on lawyers and agents appearing in the Court was removed. The Native Land Amendment Act, s 3 of that year gave the Court power to "allow counsel or agent to appear for either party in a case, and to conduct such case on behalf of such party". It was said in parliament that this change had been made because Māori themselves had requested it, and that the change was also supported by the judges: (28 July 1878) 28 NZPD 3. It appears, however, that Māori were divided in their views as to whether lawyers should be able to practise in the Court, and some groups petitioned for the ban to be reimposed. The Native Land Laws Amendment Act 1883, s 4 reimposed the ban on lawyers, which must have struck a blow at the large and lucrative Māori land practices of lawyers such as John Sheehan, Walter Buller, and William Rees, but in 1886 the ban was once again removed, this time by the Native Land Court Act 1886, s 65. There were thus two periods of exclusion, from 1873-1878 and from 1883-1886. From 1886 counsel have regularly appeared in the Court and, of course, still do so today. None of the bans would have prevented Māori from consulting lawyers outside the courtroom, and it seems that many did so. Obtaining legal services is simply a mark of growing commercial sophistication. 
come out of the cases much better if they had had one, not that there were any to be found in the Chatham Islands in 1870.

The existing secondary literature on the Native Land Court has now been vastly enriched by research done for the Waitangi Tribunal. The Native Land Court has turned to be a key issue for the Tribunal, and an intractable one. In its report on the Gisborne claims (Turanga) the Tribunal devoted 140 pages of closely-focused text to the Native Land Court, taking a "fresh perspective" in the hope that "we might finally resolve one of the enduring subjects of debate between Crown and claimants in Treaty jurisprudence and historiography". ${ }^{11}$ Such resolution in fact still seems some way off. Following Turanga (2004) the Tribunal felt it necessary to discuss the Court at length again in its Central North Island (2008), ${ }^{12}$ Kaipara (2006) $)^{13}$ and Hauraki reports (2006). ${ }^{14}$ In its Central North Island Report the Tribunal noted that notwithstanding that "the operations of the Native Land Court and their impact on Māori communities have been key issues in many previous Tribunal inquiries", nevertheless "these issues remain some of the most important and most contested in the Central North Island inquiry". ${ }^{15}$ In its Urewera report (2009-2010) the Tribunal understandably stated that enough was enough, and confined itself to reporting on particular blocks rather than yet again traversing general matters about the Court and the Native Lands Acts: ${ }^{16}$

We are fortunate to be reporting at a time when there is a wealth of published Waitangi Tribunal reports about the Native Land Court system. Having studied the evidence presented to us and the earlier Tribunals' reports, we are satisfied that a number of generic issues about the Court regime have now been so well-explored and authoritatively determined that there can be no justification for our retraversing them.

Nevertheless the Urewera Tribunal still had to invest much time and effort into inquiring into particular actions and decisions of the Native Land Court. In the Whanganui inquiry, closing submissions presented to the Tribunal this year (2010) once again revisited the Native Land Court and Crown purchasing issues at length, partly in response to new material placed on the record by Crown counsel. Although the Tribunal may well be feeling more than a little jaded with the subject of the Native Land Court, it cannot be avoided, and if new evidence puts in doubt conclusions reached in earlier reports it is hard to see how the Tribunal can simply rely on its earlier findings.

11 Waitangi Tribunal Turanga Tangata Turanga Whenua: The Report on the Turanganui a Kiwa Claims (2004) Wai 814, 397 (Turanga report).

12 Waitangi Tribunal He Maunga Rongo: The Report on the Central North Island Claims (2008) Wai 1200.

13 Waitangi Tribunal Kaipara (2006) Wai 674.

14 Waitangi Tribunal Hauraki (2006) Wai 686.

15 Waitangi Tribunal He Maunga Rongo: The Report on Central North Island Claims above n 12, vol 2, at 446.

16 Waitangi Tribunal Te Urewera, Wai 894 (2nd pre-publication release, July 2010) at 497 
Despite a great deal of research and effort on the part of historians, and a determination on the Tribunal's part to lay this particular ghost to rest, somehow it manages to keep reviving and to carry on haunting all players in the current Waitangi Tribunal and Crown-Māori settlement processes. Besides, history can never be authoritatively settled, as those familiar with such endless debates as the origins of the English Civil War, the decline of Rome or the significance of the voyages of Christopher Columbus will know.

Since 2001 new research on the Native Land Court has proliferated. While this material has been produced for a judicial process, nevertheless most historians involved in it have maintained high professional standards and have tried not to let the somewhat artificial context of the Tribunal interfere too much with the production of reliable and robust history. Some representative important Waitangi Tribunal claimant research reports that deal to varying degrees with the Native Land Court include David Armstrong and Evald Subasic's Northern Land and Politics (2007), ${ }^{17}$ Angela Ballara's Tribal Landscape Overview for Taupo, Rotorua and Kaingaroa (2004), ${ }^{18}$ Judith Binney's Encircled Lands (2002, 2009), ${ }^{19}$ Bruce Stirling's Taupo-Kaingaroa Overview (2004), ${ }^{20}$ Stirling's Wairarapa Maori and the Crown (2002), ${ }^{21}$ and Tony Walzl's Ahuriri Land Issues (1997). ${ }^{22}$ All of these are serious and comprehensive scholarly works. Also important are the various Block Research Narratives prepared by Paula Berghan of Walghan Partners, and detailed studies of particular blocks or districts by, for example, Philip Cleaver (1999), ${ }^{23}$ Mary Gillingham (2001), ${ }^{24}$

17 David Armstrong and Evald Subasic "Northern Land and Politics: 1860-1910: An Overview Report prepared for the Crown Forestry Rental Trust" 2007, Wai 1040 Doc\#A12.

18 Angela Ballara "Tribal Landscape Overview, c 1800-1900 in the Taupo, Rotorua, Kaingaroa and National Park Inquiry District" (research report commissioned by the Crown Forestry Rental Trust, 2004) Wai 1200 [Central North Island Inquiry] Doc\#A65.

19 Judith Binney "Encircled Lands: Part One: A History of the Urewera from European Contact until 1878: An Overview Report", research report commissioned by the Crown Forestry Rental Trust, 2002, Wai 894 [Urewera Inquiry] Doc\#A12; Binney "Encircled Lands, Part Two: A History of the Urewera, 1878-1912: An Overview Report" (research report commissioned by the Crown Forestry Rental Trust, 2002) Wai 894 Doc\#A15. Binney later consolidated her two reports into her book Encircled Lands: Te Urewera, 18201921 (Bridget Williams Books, Wellington, 2009).

20 Bruce Stirling "Taupo-Kaingaroa Nineteenth Century Overview" (research report commissioned by the Crown Forestry Rental Trust, 2004) Wai 1200 [Central North Island Inquiry] Doc\#A71. This is a massive study of some 1655 pages.

21 Bruce Stirling "Wairarapa Maori and the Crown" (2002) Wai 863 Doc\#A50.

22 Tony Walzl "Ahuriri Land Issues" (research report commissioned by Nga Hapu o Ahuriri in association with the Crown Forestry Rental Trust, 1997) Wai 201 [Mohaka ki Ahuriri] Doc A05.

23 Philip Cleaver "Matahina Block" (research report commissioned by the Waitangi Tribunal, 1999) Wai 894 Doc \#A63. 
Peter McBurney (2001, 2004), ${ }^{25}$ Cathy Marr (2004) ${ }^{26}$ Tracy Tulloch $(2001,2002)^{27}$ and other scholars, including myself $(1998,1999) .^{28}$ There has also been some important work done on the Court as an institution for the Waitangi Tribunal process, including Don Loveridge's analysis of the Court's origins (2001), ${ }^{29}$ Bryan Gilling's analysis of the background and qualifications of the judges (1994), ${ }^{30}$ Keith Pickens' studies of the Court's operations in various regions $(2004,2005)^{31}$ and Bob Hayes' work on the Native Lands Acts and the Rees-Carroll Commission of 1891 (2001, 2008). ${ }^{32}$ As can seen most of this work is comparatively recent. Anyone now wishing to pass judgment on the Native Land Court has no option but to familiarise themselves with it. Without this body of research certainly a scholarly edition of the Court's judgments could not have been contemplated.

24 Mary Gillingham "Waitaha and the Crown, 1864-1981" (research report commissioned by the Crown Forestry Rental Trust on behalf of the claimants, 2001) Wai 1200 [Central North Island Inquiry] Doc\#A35. Waitaha are an iwi of the Bay of the Plenty coast.

25 Peter McBurney "The Court Cases of Nireaha Tamaki of Ngati Rangitaane, 1894-1901" (research report commissioned by the Crown Forestry Rental Trust, 2001) Wai 863 Doc\#A24; Peter McBurney "Ngati Manawa and the Crown, 1840-1927" (research report commissioned by the Crown Forestry Rental Trust on behalf of the claimants, 2004) Wai 894 [Urewera Inquiry] Doc\#B5.

26 Cathy Marr "The Waimarino Purchase Report: The Investigation, Purchase and Creation of Reserves in the Waimarino Block, and Associated Issues" (research report commissioned by the Waitangi Tribunal) Wai 903 [Whanganui Inquiry], Doc\#A60.

27 Tracy Tulloch "Heruiwi Blocks 1-4" (research report commissioned by the Waitangi Tribunal, 2001) Wai 894 [Urewera] Doc\#A1; "Whirinaki" (research report commissioned by the Waitangi Tribunal, 2002) Wai 894 Doc A9. Heruiwi and Whirinaki are two large adjoining blocks in the Kaingaroa-Urewera region.

28 Richard Boast "Petane and Te Pahou Blocks" (research report commissioned by the Waitangi Tribunal, 1998) Wai 201 [Mohaka ki Ahuriri Inquiry], Doc\# T15; "Ngati Whare and Te Whaiti Nui-a-Toi: A History" (research report commissioned on behalf of the claimants, 1999) Wai 894 [Urewera] Doc\#A7.

29 Don Loveridge "The Origins of the Native Lands Acts and the Native Land Court in New Zealand" (research report commissioned by the Crown Law Office, 2001) Wai 1200 [Central North Island] Doc\#A72.

30 Byran Gilling "The Nineteenth-Century Native Land Court Judges: An Introductory Report" (research report commissioned by the Waitangi Tribunal, 1994) Wai 814 [Gisborne Inquiry] Doc\#A78.

31 Keith Pickens "Introduction and Operation of the Native Land Court in the Central North Island" (research report commissioned by the Crown Law Office, 2004) Wai 1200 [Central North Island Inquiry] Doc\#A78; "Operation of the Native Land Court in the National Park Inquiry District in the $19^{\text {th }}$ Century" (report Commissioned by the Crown Law Office, November 2005) Wai 1130 Doc\#A50. Dr Pickens had to endure prolonged cross-examination from claimant counsel in the National Park inquiry for suggesting that the Native Land Court did not deserve all the blame that has sometimes been heaped upon it.

32 Robert Hayes "Native Land Legislation, Post-1865 and the Operation of the Native Land Cout in Hauraki" (research report commissioned by the Crown Law Office, 2001) Wai 686 [Hauraki Inquiry] Doc\#Q1; "A Study of the Uses and Misuses of the 1891 Native Land Laws Commission" (research report commissioned for the Crown Law Office, April 2008). 
Not all of the traditional critiques of the Court have been shown to be wholly unfounded as a result of this new research. In particular the standard picture of the chaos, unhealthiness and hard drinking that typified the Court towns such as Cambridge, Marton and Waipawa is all too true. But it has become clear there were a number of weaknesses with the traditional interpretation. Most seriously, it was not founded on a really detailed understanding of the working of the Native Lands Acts. Much of the condemnation of the Native Land Court actually rested on quite a narrow evidentiary base and a limited consideration of the details of the legislation. Another problem was that very little basic statistical research had been done on Māori land alienation in the period from 1865 to 1920. It seems to have been assumed that with the enactment of the Native Lands Acts, set up to facilitate the alienation of Māori land to "settlers", that it was private purchase which became dominant after 1865, replacing the former pre-emptive regime. It thus came as something as a surprise that when the basic statistical work was finally done by Loveridge (2004) and others it became clear that even after 1865 the dominant purchaser, indeed by a huge margin, continued to be the state. ${ }^{33}$ If it was true that the Court was set up to make land directly alienable to "settlers", why was it that the dominant purchaser of Māori land continued to be the government? New questions have come to be asked about the Court's procedure. Was it, for instance, actually true that the Court proceeded to hear cases when some of the parties were not present in Court? In fact it seems that adjournments by the Court because Māori were not ready to proceed, needed to return to their cultivations, or could not or were prevented from attending were routine.

Moreover, the only approach to the Native Land Court in the traditional historiography was a critical one. No one had anything positive to say about the Native Land Court or its judges. In fact it is becoming clear that there is another side to the story. Sometimes the Court did manifest a robust judicial independence. Relationships between the Native Land Court and the Government could often be tense and even hostile. It seems, too, that there was no rule that those classed as 'rebels' were debarred from bringing claims in the Native Land Court, and little to show that the Court favoured "loyalists" over "rebels" in its awards and allocations. Nor were the judges all blinkered ideologues with no understanding of Māori social organisation. Many of the judges, few of whom were lawyers, had had some exposure to the Māori world and did not in fact believe that Māori was made up of large tribes subdivided into hapu and whanau in a tidy hierarchy. The Native Land Court always saw itself as a Court which applied Māori customary law, not as a body which had a mission to eradicate it, and if its understanding of this law was not exactly the same as that of modern ethnographers, nevertheless it certainly accepted the validity of Māori customary law and at least

33 Don Loveridge "Development of Crown Policy on the Purchase of Maori Land: A Preliminary Survey" (research report commissioned by the Crown Law Offiice, 2004) Wai 1200 Doc\#A77. See also RP Boast Buying the Land, Selling the Land: Governments and Maori Land in the North Island 1865-1921 (Victoria University Press, Wellington, 2008) at 32-40. A number of historians had suspected as much, but Loveridge deserves credit for establishing the point comprehensively. See also Tom Brooking "'Busting Up' the Greatest Estate of All: Liberal Maori Land Policy, 1891-1911" (1992) 26 New Zealand Journal of History 78. 
some of the time did its best to defend and apply it. "[T]he principles of Māori Law on which this Court has always acted", as Chief Judge Fenton put it in one case, "are very simple, very intelligible, and in truth could not be otherwise". ${ }^{34}$ Grant Young has in my opinion completely demolished the myth that the Native Land Court rigidly and consistently applied narrowly defined "take", although sometimes it did: the Chatham Islands cases can be seen as an example. ${ }^{35}$ Nor is it true that all lawyers who practised in the Court were crooked shysters (surely no one could say that of Sir Robert Stout) - but then again some probably do deserve to be seen as such.

No new consensus on either the Court or the Native Lands Acts appears to have emerged so far. This article, and the edition of judgments that I am now working on, arises from the simple conviction that one good way of coming to grips with the effects and significance of the Court's work comes from a close analysis of its actual decisions and its modus operandi.

\section{LOCATING THE JUDGMENTS OF THE NATIVE LAND COURT}

\section{A The Records of the Native Land Court}

The primary source for the judgments are the Court's manuscript records, usually referred to as "minute books". The minute books are generally unloved by historians. As Keith Pickens has written: ${ }^{36}$

The limitations of the Native Land Court minute books are well known. They are, normally, notes in

English, of evidence originally given in Māori. The accuracy of the translations and transcriptions is

unknown. The quality of the original evidence itself cannot be assessed. Even as a simple record of

proceedings, the minute books are sometimes deficient.

All too true. On the other hand, the Land Court minute books must be far the biggest and bestpreserved set of original material from any 19th century New Zealand Court to survive intact until the present day. What is left to us of the evidence and submissions given even in the Supreme Court, for example, is nowhere near as complete.

Transcribing judgments, or indeed anything, from the minute books is an arduous undertaking as anyone who has attempted it will be well aware. The minute books are folio leather-bound books which the Court transported about from place to place in which the clerk of the court recorded what

34 Native Land Court judgment in Mohakatino Parininhi case (1882) 1 Mokau-Waitara MB 48-52, at 51. This is a very controversial case, as it happens, in which Ngati Tama lost their interests in their ancient homeland of Poutama on the basis that they had been defeated by Ngati Maniapoto and had abandoned their traditional territories.

35 Grant Young "Judge Norman Smith: A Tale of Four 'Take"' (2004) 21 NZULR 309.

36 Keith Pickens "Operation of the Native Land Court in the National Park Inquiry District" Wai 1130 Doc\#A50 at 4 
transpired in the courtroom. The bulk of the surviving material is comprised of the evidence given in Court. The evidence is massive in scale. Witnesses sometimes spoke for days on end. They were often cross-examined at great length and interrogated closely by the Court. Although crossexamination is normally perceived as an activity carried out by barristers, Māori bringing cases in the Court were not shy about cross-examining one another, and often did so with great élan and effectiveness and sometimes at considerable length. The longest cross-examination in the Native Land Court I have found so far is that of Tauha Nikora, the claimant in the huge Tahora No 2 block case heard at Opotiki in 1889. Tauha Nikora was cross-examined not by lawyers but by Wi Pere, Erueti Tamaikoha, and other chiefs of the Urewera and Gisborne regions: the cross-examination lasted from 18-27 March 1889 and takes up 98 pages of the minutes. ${ }^{37}$ The minute books also contain the Court's judgments, usually written out in longhand.

The minute books, kept by the clerk of the Court, appear to have been regarded as official records and were the property of the Native Land Court as such. The judges themselves had separate minute books of their own, their own property, and sometimes these have survived as well, and there was a further series of Chief Judges' minute books. Sometimes the judge's minute books have been added to the public records, meaning that for some times and places there is now a double record that can be consulted. One key difference between the judge's minute books and those of the court is that in the former opening and closing addresses of counsel are recorded in full, which are then fully annotated by the judge during the process of writing the judgement. For example in the case of WH Rees' closing address in the Omahu rehearing, made on 16 March 1892, one can still see Judge Scannell's annotations, highlighting references to the evidence, statutory provisions and case law, and also commenting on the argument ("not in point," "?very doubtful," "highly probable," "the hearing at Pawhakairo proves nothing," and even "nonsense"). ${ }^{38}$ The ordinary minute books tend not to record counsel's addresses, presumably because these did not form part of the official record, although sometimes where a closing address was recorded in the local newspaper this can be found pasted into the minute book at the appropriate place. If Judge Rogan, who heard the Chatham Islands cases, ever kept a personal set of minute books these have not survived. The only record is what is found in the official Chatham Islands minute books.

As Dr Pickens points out in the passage cited earlier, the language of the minute books is mostly ${ }^{39}$ - English. The record of the Chathams Islands cases of 1870 is an example: the whole record is in English. This poses an obvious problem given that the actual language in the proceedings in court would have been Māori, for the most part. Whether the Moriori lanuage was at all used in the 1870 Chatham Islands cases is unknown. The early judges such as Monro, Fenton and

37 See (1889) 5 Opotiki MB 165-263. Tahora No 2 was a block of some 213,000 acres. On this block see Waitangi Tribunal, Te Urewera (Second Pre-publication release, July 2010) at 553-575.

38 (16 March 1892) 25 Judge Scannell MB at 453- 456.

39 Some of the Maketu minute books are entirely in Māori, and there may be others. 
Rogan could all speak Māori, although with what degree of fluency I would not care to say, and certainly the evidence in court would have been given in Māori. Other judges, especially later in the Court's history, did not always speak Māori well (or at all), which would have meant that questions from the bench would have been put in English, translated, and replies of the witness likewise translated and written in the minutes. Questions from the assessor would usually have been in Māori, with questions and answers both being translated. The assessor's questioning in the Chatham Islands cases, excerpted below, is an example: undoubtedly these exchanges would have been in Māori. Judgments were usually written and read out in English and translated into Māori by the Court translator. There must have been a degree of regional variation, with more evidence and questioning in English in parts of the country where British settlement was long-established, as in the South Island and Hawke's Bay, as compared with still largely Māori regions such as the inland Bay of Plenty, Taupo, the King Country and Te Urewera.

The minute books, it is important to point out, are not the only form of record left by the Court. The Native Land Court worked by orders, usually filling in printed forms which were in English and Māori, copies of which were filed in the Court registry organised under block names, thus creating "block files", or "block order files". These often very bulky files contain duplicates of the formal orders made by the Court: title orders, succession orders and so on. In accordance with standard judicial practice, one copy of the order would be given to the parties and the other retained by the Court itself. It was and is the formal orders, not the minute books, which give binding effect to the Court's decisions. The minute books are merely a record and have no legal standing. Once a block ceased to be Māori freehold land, for example when it was sold to a private purchaser or proclaimed Crown land, the block order file would be closed as the Court would no longer have jurisdiction over that particular piece of land. These "closed files" are nevertheless an important record in their own right and are routinely used by researchers. The Court also maintained - and maintains correspondence files, also usually arranged by block, which contain letters from Māori people, surveyor's reports and other such material. This material is also very valuable, and there, as with the block order files, closed correspondence files as well. These correspondence files contain a vast treasure trove of nineteenth-century written Māori, which one day, no doubt, some historian with the right linguistic and historical tools will do something very interesting with.

\section{B Judgments in Print}

Although no proper series of law reports for the Native Land Court exists, a reasonably substantial number of Court decisions are in fact in print, although not in any kind of systematic way.

First, there is one small volume printed in 1879 which reprints the decisions of a number of decsions of the Native Land Court under the name of Francis Dart Fenton, the first Chief Judge of 
the Native Land Court and principal author of the Native Lands Act $1865 .^{40}$ It contains only nineteen judgments in total, four from the Compensation Court and fifteen from the Native Land Court. This small sample raises the question as to what the purpose of this volume might have been and the criteria for selection. (The Chatham Islands cases, for instance, obviously important decisions, are not included.) The brief preface to this volume indicates that the cases were selected primarily for their historical interest, rather than as contributing towards the development of legal principle: ${ }^{41}$

In consequence of applications made from time to time for copies of Judgments delivered in Compensation Court and Native Land Court, it has been thought advisable to print all the more important of these in a collective form, so as to be easily accessible by persons requiring such, and also as a record of some of the most interesting events in Native history. ... Many of these Judgments will therefore be found to contain interesting records of Native history for a period of 200 years preceding the present time, and will prove of great assistance to any one who may hereafter compile a complete history of the Native race.

The collection is thus aimed at those interested in Māori tribal history. Fenton's book contains nothing by way of explanatory commentary, nor are the judgments themselves prefaced by headnotes explaining who the parties were and the issues at stake. The book is quite unlike a volume of the law reports. Moreover the style of some of the some of the judgments, for example that given by Judge Maning and Judge Monro in the Te Aroha rehearing case, is in a high Victorian literary mode, full of ponderous circumlocutions and with some rather highly coloured descriptions of war and bloodshed replete with "vigorous" and "exulting warriors", "fierce reprisals", "glowing ovens" and "roasting flesh". ${ }^{42}$ Who was this written for? Surely not for the anxious claimants and counterclaimants of Ngati Haua, law-abiding Christians by 1872 who wanted to know only to whom the land was to be allocated. The judgment in this case was, it seems to me, written for a European audience and reads like a mixture between the ethnography of the day and a novel by Sir Walter Scott. The judgment was written for publication, in fact. This was untypical, and the Chatham Islands judgments are not of this character.

Many Court judgments were printed verbatim in the newspapers. In fact newspapers are the second most important source after the minute books themselves. Sometimes the judgment can only be found in the newspapers. In some instances there is no judgment in the minutes and there is

40 Francis Dart Fenton Important Judgments delivered in the Compensation Court and Native Land Court 1866-1879, Published under the Direction of the Chief Judge, Native Land Court (Henry Brett Printers, Auckland, 1879) ("Important Judgments"). The collection was reprinted by Southern Reprints in 1994.

41 Fenton, Important Judgments, ibid, Preface (not paginated).

42 Ibid, at 112 (Te Aroha judgment, 1872). 
simply a note to refer to the newspapers. ${ }^{43}$ Much more often the newspaper version of the judgment is pasted directly into the Minute Book by the Judge or the clerk, presumably to save themselves the trouble of copying out the judgment and also to keep a record. The Te Aroha rehearing (1871) and Omahu cases (1890), are examples. Some judgments are printed in the Appendices to the Journals of the House of Representatives (AJHR), usually as part of the record of an inquiry of some kind into a particular block or issue. The endless complexities over land titles, the Court process, and Crown and private sector purchase of Māori land generated a torrent of petitions to parliament and to the government, some of which resulted in commissions of inquiry or Royal commissions. When these bodies reported the printed report often contained a reprint of whatever judgments of the Native Land Court were relevant, and sometimes of the evidence as well. An example are the cases dealing with Maungatautari, a bitterly-contested area which saw a number of cases in the Court but also many petitions and official inquiries. Such reprints, although infrequent, are a godsend as they provide a fully printed and legible text of the decision of the Court and of the evidence, making transcription obviously comparatively simple.

In the case of the Chatham Islands cases, however, the only surviving record of the Court's decision and of the evidence is what is written down in longhand in volume 1 of the Chatham Islands minute books. No newspaper accounts of the decisions have come to light. Until this article the full texts of these judgments have never appeared in print before.

\section{THE CHATHAM ISLANDS DECISIONS: A CASE STUDY}

\section{A Introduction}

The Chatham Islands are located about $900 \mathrm{~km}$ east of Banks Peninsula and are comprised of two main islands, Chatham Island (Rekohu in Moriori and Wharekauri in Māori) and Pitt Island (Rangiauria) which together have a surface area of about 100,000 hectares or 240,000 acres. The Chatham Islands decisions of 1870 awarded the overwhelming bulk of interests in the islands to Ngati Mutunga, who, along with Ngati Tama, arrived at the islands from Wellington in 1835 and conquered and enslaved the indigenous Moriori inhabitants, killing many of them in the process. Here it was Māori who were the colonisers. To get to the islands Ngati Mutunga and Ngati Tama chartered a British trading vessel that had come to Wellington harbour. Atholl Anderson has suggested that this invasion and settlement of the Chatham Islands by North Taranaki groups should be seen as part of a new phase of Polynesian colonisation in South Polynesia in the 19th century "actuated significantly by European geographical knowledge and technology, especially of seafaring" - other examples being Māori settlement on Lord Howe Island from 1834-1841, Māori

43 In the Tiritiritangi case heard at Auckland, presided over by Fenton: see (1867) 1 Auckland MB 101: "The Chief Judge delivered the judgement [sic] of the Court, for report of which: see papers." 
and Moriori settlement in the Auckland Islands from 1842-1856, and the migration of the Pitcairners to Norfolk Island in $1856 .{ }^{44}$

There was also some temporary compulsory Māori settlement on the islands. From 1866-68 the Chatham Islands were briefly used as a penal colony for Māori rebels. The use of transportation as a government response to Māori "rebellion" has never been systematically studied. Until 1859 transportation was still the main criminal sentence used in New Zealand (convicts were shipped to Van Diemen's Land). Sending people perceived to be troublesome into exile was thus standard practice at the time, and during the New Zealand wars it was used to a significant extent. Some Māori prisoners were held on hulks in the Waitemata harbour, while those from the East Coast, following the battles at Waerenga-a-Hika in 1865 and Omarunui in 1866 were sent to the Chathams. The Chatham Islands were seen by the government as a suitable place for a penal colony principally because of their isolation and because comparatively few people lived there. ${ }^{45}$ The transportees - it would not be correct to describe them as 'convicts', as some historians do, ${ }^{46}$ given that none of them had been convicted of anything - lived in a row of ponga houses at Waitangi, the main settlement. They were under the supervision of the resident magistrate, William Thomas, and an armed guard of about twenty-six men, half of whom were themselves Māori. The transportees built a redoubt at Waitangi, and a three-celled prison, grew their own vegetables, and upgraded tracks and roads. ${ }^{47}$ In July 1868, after the exiles had been on Wharekauri for nearly two years, the transportees, led by Te Kooti, executed a daring escape. They seized the Rifleman, a schooner chartered by the government to bring supplies from Napier to the Chathams, sailing from from Wharekauri with 298 exiles on board, 163 men, 64 women and 71 children. ${ }^{48}$ The Waitangi Tribunal, in both its Mohaka ki Ahuriri and its Turanga reports has concluded that there was no justification for the detention without trial on the Chathams of either the 1865 Turanga prisoners, sent there in the wake of Waerenga-a-Hika,

44 Atholl Anderson "Retrievable Time: prehistoric colonisation of South Polynesia from the outside in and the inside out" in Tony Ballantyne and Brian Moloughney (eds) Disputed Histories: Imagining New Zealand's Pasts (Otago University Press, Dunedin) 25 at 41. This is an interesting perspective, although these later phases of Polynesian settlement have as many dissimilarities as similarities. The part-Tahitian Pitcairners went to Norfolk at the invitation of, and with the assistance of, the British government with the closure of the Norfolk convict settlement, and can hardly be compared with the invasion and conquest of the Chathams. On Norfolk see especially Raymond Nobbs Norfolk Island and its Third Settlement: The First Hundred Years: The Pitcairn Era and the Melanesian Mission (Library of Australian History, Sydney, 2006).

45 Lyndsay Head "Friend Ritchie": Maori Letters to a Chatham Islands Runholder 1869-1932 (edited typescript held in Chatham Islands museum, Waitangi) 34.

46 Michael King Moriori: A People Rediscovered (Viking, Auckland, 1989) at 105-106.

47 King Moriori, ibid, 106.

48 Judith Binney Redemption Songs: A Life of Te Kooti Arikirangi Te Turuki (Auckland University Press, Auckland, 1995) at 84 
or of the Hawke's Bay prisoners sent there in the latter part of $1866 .{ }^{49}$ That being the case, it follows that the prisoners detained on the Chathams were being held illegally and had every right to escape. 50

Just two years after the escape the Native Land Court made its first visit to the Chatham Islands and decided the cases reprinted in the Appendix. These decisions have been seen as quintessential illustrations of the Native Land Court's "1840 rule," by which the Court made its decisions based on whoever had title according to Māori customary law in 1840, and of its doctrine of take raupatu, or title by conquest. Critical views of the 1870 decisions can be found in Michael King's history of the Moriori people, ${ }^{51}$ and in Bryan Gilling's article "By Whose Custom?". ${ }^{52}$ In its Rekohu (Chatham Islands) report the Waitangi Tribunal was constrained by the fact that it does not sit as a review or appellate body with respect to decisions of the Native Land Court. Nevertheless it had a number of critical remarks to be made about the Court process as well as the Government's failure to intervene. It stated that the competing claims in the Chatham Islands should not have been referred to the Court at all because "the statutory framework of the Act was too narrow for true justice to be done in this case." 53 The Tribunal believed that "a different result would have followed if a Māori panel had been asked to decide this case", a very questionable assumption. ${ }^{54}$ A number of research reports prepared for the Chatham Islands enquiry by myself, Bryan Gilling, Grant Phillipson, Fergus Sinclair and Tony Walzl, prepared variously for Moriori, Ngati Mutunga, and the Crown, considered the cases fully from a variety of perspectives. ${ }^{55}$ The Waitangi Tribunal's handling of the

49 See Waitangi Tribunal Mohaka ki Ahuriri Wai 220; Turanga, above n 11, at 192-193.

50 Waitangi Tribunal Turanga Report, ibid, 194.

51 King Moriori, above n 46, at 23-34. King argues that tactically the Moriori case was "poorly presented" (at 132 ) - that is, their dwelling on the hardships and cruelties inflicted on them by the conquest only served to reinforce the Ngati Mutunga case.

52 Bryan Gilling "By Whose Custom? The Operation of the Native Land Court in the Chatham Islands (1993) 23 VUWLR 45. Gilling develops here the argument that the real problem with the decisions is that it applies Māori customary law without taking any account of Moriori customary law; the same point is made by King Moriori, above n 46,132.

53 Waitangi Tribunal Rekohu, above n 2.

54 Waitangi Tribunal Rekohu, above n 2, 148-150. It might be just as likely that a Māori panel in 1870 would have had the same robust views about conquest as did Rakataau and Wi Naera Pomare of Ngati Mutunga. In any case the Court had a bicultural membership, made up a judge (Rogan), and a Māori assessor, Charles Wirikake. In this case the assessor clearly played a very active role in the case, questioning witnesses for both sides closely (as is evidenced in the minute book). The notion that the assessors were non-entities who played no real role in the cases is a myth.

55 Richard Boast Ngati Mutunga and the Chatham Islands: A report to the Waitangi Tribunal, (1995) Wai 64 Doc\# J6; Bryan Gilling, The Native Land Court in the Chatham Islands (report commissioned by Te Iwi Moriori Trust Board, 1993) Wai 64 Doc\# A10; Grant Phillipson Report to the Waitangi Tribunal on matters of relevance to the Chatham Islands Claims Wai 64, including the intervention of the Government in the affairs of the Maori Land Court (report commissioned by the Waitangi Tribunal, 1994) Wai 64 Doc\# A16; 
Chatham Islands claims has been considered critically by Michael Belgrave. ${ }^{56}$ The events which underpinned the 1870 hearings have also been the subject of a full-length feature film, directed and written by Barry Barclay, The Feathers of Peace (2000), which portrayed the story of invasion, massacre and enslavement in 1835 in a dramatised documentary style. ${ }^{57}$

\section{$B$ The Opening of the Hearings and the Claimant Case}

The 1870 cases were the first Land Court decisions relating to the Chatham Islands, and were heard at Waitangi, on Chatham Island, which was also where the judgments were delivered and which had been the site of the former penal settlement. The Native Land Court went to the Chatham Islands infrequently. The next entry in the Chatham Islands Minute Book after 1870 is in 1881 (after that the Court went to the islands at two to five-yearly intervals). By the time of the 1870 hearings the islands had already been split into six large blocks. Māori had arranged with a Mr Ford to survey the blocks and his survey party joined up with the government's triangulation team to survey the island. ${ }^{58}$ Possibly some of the Moriori reserves may have been marked out at this point.

Seven blocks were in issue: Mangatu Karewa, also known as Kekerione, Te Matarae, Te Awapatiki, Otonga, Wharekauri, Rangatira Island, a small offshore island, and Rangiauria (Pitt Island). Not all the blocks were contested. Te Matarae block was contested not by Moriori but by two rival sections of Ngati Mutunga - the Kekerewai descent group led by Rakataau, who was supported by Moriori and part-Moriori witnesses, and by Ngati Mutunga counterclaimants, Hamuera Koteriki and Apitia Punga representing hapu distinct from the Kekerewai. There was no separate Moriori counter-claim to this block. Otonga and Wharekauri blocks were wholly uncontested, and the titles and Moriori reserves appear to have been sorted out by agreement. The blocks that were contested between Ngati Mutunga and Moriori were Kekerione, Te Awapatiki and Rangiauria. The Court wrote formal judgments only on Kekerione, Te Matarae and Te Awapatiki, but it also made orders with regard to Otonga, Wharekauri and Rangiauria. The claim to Rangatira Island, made by Maniu Te Teira (who was Moriori), was abandoned as no survey plan had been done.

The principal claimant to Kekerione was Wi Naera Pomare, a chief of the Ngati Mutunga people. One way to contextualise the Chatham Islands cases is to look at the main Ngati Mutunga claimant closely. Wi Naera Pomare played no role in the invasion of the Chathams himself, being

Fergus Sinclair Native Land Court on the Chatham Island (1995) Wai 64 Doc\# L1; Tony Walzl The Native Land Court and the Chatham Islands, 1900-1955 (1995) Wai 64 Doc\#K15 [deals with later phases of the Court's history in the islands].

56 Michael Belgrave Historical Frictions: Maori Claims and Reinvented Histories (Auckland University Press, Auckland, 2005).

57 The Feathers of Peace He Taonga Films 2000 (direction and screenplay by Barry Barclay).

58 According to the evidence of Alexander Shand, at (1900) 3 Chatham Islands MB 55. 
only a young child growing up with his Ngati Toa mother at Porirua at the time. According to one writer "he was a much loved, quiet kindly man and very much under his wife's thumb." 59 Wi Naera Pomare's family connections and his own life are a virtual microcosm of many of the most important events of 19th-century Māori history. His father was English, a Captain Blenkinsopp, commander of the whaler Caroline, who was engaged in some dubious land transactions in the northern South Island. Wi Naera Pomare's mother was Ngati Toa: Orongo, also known as Te Rongo, a relative of Nohorua, Te Rauparaha's elder brother. After Blenkinsopp's death Te Rongo married Te Rangihaeata, the great Ngati Toa chief. She died at the battle of the Wairau in 1843 when hit by a stray bullet. ${ }^{60}$ It was for this that Te Rangihaeata exacted utu on the New Zealand Company captives, killing all the prisoners after Ngati Toa's defeat of the armed party led by the Nelson magistrates. Wi Naera, Te Rongo's son by her first marriage, was adopted by Wiremu Piti (that is William Pitt - his baptismal name) Pomare, presumably after the death of the boy's mother at the Wairau. Wiremu Piti Pomare was one of the leaders of the invasion of 1835 and was the successor to Patukawenga as leading chief of Ngati Mutunga; Pomare died at the Chathams in 1851. Wi Naera Pomare and his wife Mere lived on the Kekerione block at the Chathams and also at Urenui in North Taranaki. He became a dedicated follower of Te Whiti and was present at Parihaka when colonial forces sacked Parihaka and took Te Whiti into custody.

Wi Naera Pomare, then, well connected to the Māori chiefly world, a Christian and later to be a supporter of Parihaka, led the Ngati Mutunga case in 1870. He handed a long list of names into Court and the following exchange then took place:

Court: Are there any Morioris in the names above given?

Wi Naera Pomare: Not any.

There were then some routine questions about the survey, as the Court could not usually investigate title to an unsurveyed block and certainly could not do so in 1870 . There was, said Wi Naera Pomare, "no opposition" to the survey. The evidence proceeds:

Court: Where do the Ngatimutunga Tribe belong to originally?

Wi Naera: The Ngatimutunga Tribe came from Taranaki.

Court: Do you know whether there will be any opposition to this claim?

Wi Naera: I believe not. I claim this land on account of my long residence on it, and having taken possession of the Island.

59 EC Richards The Chatham Islands: the plants, birds and people (Simpson and Williams, Christchurch, 1952) at 158.

60 Angela Ballara "Te Rangihaeata ?-1855" (2007) Dictionary of New Zealand Biography <www.dnzb.govt.nz>. 
Court: How was it you took possession?

Wi Naera: By the power of my arm we took possession. I believe it was in the year 1836 we took possession of this island.

Court: Did you find any inhabitants on the Island?

Wi Naera: We found inhabitants in 1836. We came and found this place inhabited and took possession, when we took it we took their mana from them and from that time to this I have occupied this land. This is the basis of my claim.

By 'I' in this passage Wi Naera Pomare means Ngati Mutunga as such, not himself directly (at the time of the invasion in 1835, as explained above, he was a young child living at Porirua). Rakataau, another of the Ngati Mutunga claimants stated: 61

We came from Taranaki to Kapiti in accordance with a previous arrangement that we should go and take possession of lands, we went to Wellington to Wairarapa and took possession of lands, thence to Queen Charlotte Sound, thence to Banks Peninsula and Otago. Some of our party went in whale ships and returned telling us about this place. They came back to Wellington and we held a meeting and discussed the question as to whether we should come here or not. We agreed that we should come and take this land, we came in a vessel from Port Nicholson and landed in Wangaroa, having arrived in Wangaroa we took possession of the land in accordance with our customs, and we caught the people. We caught all the people, not one escaped, some ran away from us, those we killed and others were killed but what of that it was in accordance with our custom. Many of these people were killed by us but I am not aware of any of our people being killed by them.

Rakataau was questioned by Judge Rogan and by the assessor, Charles Wirikake. Part of the exchange was as follows:

Court: Are any of the Morioris who were in your settlement alive?

Rakataau: Yes there are some here.

Court: Did you hold them in any respect or hold them as slaves?

Rakataau: We made slaves of them from the first.

Court: Did any of their Chiefs attack you in revenge for having conducted yourselves to them in this way?

Rakataau: No.

(By the Assessor): Did they wish to send you away or take back the land? 
Rakataau: No - not in times past but only lately.

Assessor: What do you say now with respect to this wish on their part to have some of this land?

Rakataau: No.

An important dimension to the cases is the Crown's confiscation of Ngati Mutunga lands in Taranaki under the New Zealand Settlements Acts. A large percentage of the Māori population of the Chathams had re-migrated back to the mainland by the time of the 1870 hearings. Many of Ngati Mutunga and virtually all of Ngati Tama returned to Taranaki in 1868, two years before the investigation of title to the land in the Chathams, in order to attend sittings of the Compensation Court and the Native Land Court there. Wi Naera Pomare, the main claimant in the 1870 investigation of title for Ngati Mutunga, later told the West Commission in 1880 that while still in the Chatham Islands "we received notice to send in our claims [to the Compensation Court], and we gave our names to Captain Thomas, then Resident Magistrate at the Chatham Islands, before we came back here". ${ }^{62}$ In fact the main sittings of the Compensation Court in Taranaki were over with two years before Ngati Mutunga and Ngati Tama left, although they probably did not realise this; the Compensation Court found that absentees, including Ngati Mutunga resident in the Chathams could make no claim to their traditional lands in Taranaki. ${ }^{63}$ Many former Ngati Mutunga residents of the Chathams remained in Taranaki, although in the 1880 s there was a re-migration back to the Chathams. The returned Ngati Mutunga lived in squalid conditions and very unsecure circumstances on a small block of land at Urenui, in North Taranaki, from 1868 to at least 1880 . The tenurial chaos in Taranaki in the aftermath of the New Zealand wars and confiscation by the Crown may explain Ngati Mutunga's determination to retain title to land in the Chathams on the basis of take raupatu. Supporting the Taranaki resistance movement centred on Parihaka may have been another factor. Ngati Mutunga are closely connected to the Te Ati Awa and Taranaki iwi of North Taranaki.

The Chatham Islands became a centre of the Parihaka movement. Most of the sources relating to the impact of the 'Parihaka movement' in the Chathams date from the $1880 \mathrm{~s}$, but it is possible that it began to work its effects much earlier than that - in fact perhaps as early as the mid 1860 s. ${ }^{64}$ Later

621880 AJHR G-2, 16.

63 On the Compensation Court in Taranaki see especially Heather Bauchop "The aftermath of confiscation: Crown allocation of land to iwi: Taranaki 1865-1880: A case study in confusion" (June 1993) Wai 143 Doc\# I18. In the Oakura decision of June 1866 the claims of the "Chatham Islanders", meaning Ngati Mutunga (and possibly Ngati Tama) to their lands in North Taranaki, which they abandoned in the 1820s, were dismissed by the Compensation Court: see FD Fenton, Important Judgments above n 40 1879, 9-12. Fenton's Important Judgments is discussed further below.

64 Bronwyn Elsmore dates the emergence of Parihaka as an important Māori political and religious centre to the mid- to late- 1860s: Elsmore Mana from Heaven (Moana Press, Tauranga, 1989) 239. Ailsa Smith sees 1865 as the key date: Ailsa Smith "Tohu Kakahi 1828-1907" (2007) Dictionary of New Zealand Biography <www.dnzb.govt.nz>. 
the Chatham Islands became a pivotal source of foodstuffs and other resources to maintain the community at Parihaka. Vast quantities of eels, duck, mutton birds and albatross were shipped from the Chathams to Parihaka, as well as gifts of money. ${ }^{65}$ Ngati Mutunga and some Moriori people in the Chathams affiliated themselves with Te Whiti and Tohu's movement of resistance and protest in Taranaki, including adopting the practice of making silent marches or pilgrimages around the land (known in the Chathams as 'waka', canoes). The government's invasion of Parihaka in 1881 and the detention of Tohu and Te Whiti did not diminish their influence in the Chatham Islands. In 1885 the Resident Magistrate (Deighton) reported that the Māori people of the Chathams "are more rabid Te Whiti-ites than formerly, so much so, that some of them are nearly almost mad on the subject". ${ }^{6}$

Another question about the 1870 hearings is the position of Ngati Tama. The invaders of 1835 were a combined force of Ngati Tama and Ngati Mutunga, yet Ngati Tama played no role in the proceedings and ended up with no interests in the Chatham Islands blocks, although presumably the Court would have recognised Ngati Tama rights on the basis of conquest had they been there. Like many of Ngati Mutunga, Ngati Tama had returned to North Taranaki in 1868. Their intention appears to have been to recover their ancient territories in the Poutama region around Mokau, by this time occupied by Ngati Maniapoto groups. There is some evidence to suggest that the attack by Ngati Maniapoto on the government redoubt at Pukearuhe in 1869 led by the Ngati Maniapoto chief Te Rerenga (at which a number of Pakeha were killed, including the missionary John Whiteley) was meant as a demonstration by Ngati Maniapoto that they would not surrender Poutama to Ngati Tama, now returned from the Chathams, and their Taranaki supporters. ${ }^{67}$ In 1882 Ngati Tama attempted to assert a title to their ancient territories in Poutama, but were unsuccessful in this: the Court awarded these lands to Ngati Maniapoto on the basis that Ngati Tama had been conquered and had abandoned the region. ${ }^{68}$ Evidence given in the Native Land Court in these cases indicates that Ngati Tama, like Ngati Mutunga, had been strong supporters of Te Whiti and Tohu at Parihaka. Tupoki Herewine Ngapiko of Ngati Tama testified in 1882 that at that time he was living at Parihaka, that he had been one of Te Whiti's ploughmen, and that he had been sent to Otago by the

65 S Deighton to Native Minister, 13 June 1885, [1885] AJHR G-2, at 21; David Holmes, My Seventy Years on the Chatham Islands (Shoal Bay Press, Christchurch, 1991); EC Richards (ed) Diary of E R Chudleigh (Simpson and Williams, Christchurch, 1952) at 158

66 S Deighton to Native Minister, 13 June 1885, 1885 AJHR G-2 at 21.

67 In 1868 the Civil Commissioner in Taranaki, Parris, reported to the government that from the perspective of Taranaki Māori "the only conclusion they can arrive at is, that the take or cause of it is the return of the Ngatitamas from the Chatham Islands; and that the Pukearuhe massacre is intended by the Ngatimaniapotos as a declaration of their intention not to surrender Poutama to the Ngatitamas": Parris to Richmond, 4 March 1869, [1869] AJHR A-10, 51, citied in Paul Thomas "Mokau, including the Mokau-Mohakatino and Mohakatin-Parininhi Blocks" (scoping report commissioned by the Crown Forestry Rental Trust for the Te Rohe Potae Claim, 2009) at 45.

68 The two key cases are Mohakatio Parininihi and Mokau Mohaktino: see (1882) 1 Mokau-Waitara MB at $48-52,71-74,85$ 
government. ${ }^{69}$ Why Ngati Tama took no steps to assert an interest in the 1870 Chathams hearings, however, is a mystery. By $1882 \mathrm{Ngati}$ Tama was left in the position of having no legally recognised rights either in the Chathams or in North Taranaki. In 1892, however, Ngati Tama were able to secure recognised interests in lands in the northern South Island based on their participation in the conquest of that region by Ngati Toa and other groups in the $1830 \mathrm{~s}^{70}$

\section{The Moriori Counterclaims}

Moriori were the counterclaimants in 1870 . They did not cross-examine the witnesses called by Ngati Mutunga, although Ngati Mutunga did cross-examine Moriori witnesses, perhaps indicating a greater degree of familiarity with Land Court procedure on the part of Ngati Mutunga. ${ }^{71}$ The Moriori case was led by Ngamunangapaoa Karaka who also handed in a long list of names into Court. Asked whether the names on the list were Māori or Moriori he stated that "some of them are Morioris and some Half-Caste New Zealanders" (New Zealanders here meaning Māori). He then gave his evidence in chief as follows:

I claim these lands through my ancestor Koke. Kahu is the name of the Chief who first arrived here, he came from Hawaiki, Rangimata is the canoe who came, Manuwake as the Chief of it, Rangihoua is another of the canoes, Korekiroa was the Chief of it. Horopuke is another of the canoes. Moe was the Chief of it. We the opposing claimants are the descendants of these people. The New Zealanders arrived in this Island in $1836,{ }^{72}$ and they took us prisoners, at that time they did not kill any of them. The New Zealanders took us and some of the men took 10 some 20 and some 50 and a hundred of our men. They landed at Wangaroa and took possession of all the land from thence to Waitangi. The Ngatitama took possession of Waitangi and the Ngatimutunga took possession of Wangaroa, at this time they commenced to kill the Morioris, they ran away and those who went to a settlement were killed, this is the way we were treated. The Māoris followed us as far as Rangiauria ${ }^{73}$ and killed us. Some of the inhabitants of Rangiauria were taken prisoners and brought to this Island. ${ }^{74}$ From the time that the New Zealanders arrived in this Island to the time when the Prisoners were taken at Rangiauria some 300 of us had been killed. My family lived with the Ngatitama tribe. The names of those I have just given are the names of the only survivors of the Moriori People. We were kept in servile bondage until the gospel was preached here; even then the wood and water were held to be sacred from us. Although we made request

69 (1882) 1 Mokau-Waitara MB 33: "I was sent there [to Otago] by the Government, as a prisoner".

70 Most importantly in the New Zealamd Company Tenths (Nelson, Moutere, and Motueka), or "Nelson Tenths" case in 1892: see the judgment of Judge Mackay in (1892) 3 Nelson MB 3-8.

71 If so this would have been because they would have learned about it by people from other areas. Ngati Mutunga in the Chathams had no real experience with the Native Land Court.

72 Sic (1835).

73 Also known as Pitt Island.

74 That is Chatham Island/Rekohu/Wharekauri. 
to have some small portions of land given to us by our masters our request was not granted. We were told by our Masters that we were to cultivate in conjunction with them, they said it would not be right for us to have separate cultivations. And down to the time when the New Zealanders leased some of the lands we desired that we might participate in the advantages derived from the Leases. They agreed to this. When they received rents we went to receive our portion but did not get any. From this we made up our minds to take up a different line of action with regard to our masters because of their innumerable acts of deceit towards us. Hence at the present day we will not obey their orders. I still hold the right to my land to this day. I wish to call Kerei, Wetini, Heremia, in order to give evidence on behalf of us in this claim.

Evidence to similar effect was given by Ngamunangapaoa Karaka's witnesses: Hirawanu Tapu, Kerei and Wetini. Wetini was asked by the Court whether the Moriori claim was particular to the Kekerione block or extended to the whole island ("the whole island" was the reply). ${ }^{75}$ After the Moriori case closed there is the following entry in the MB:

Hirawanu Tapu one of the opposing [Moriori] claimants addressed the Court in support of his claim. His Honor did not wish this statement taken down.

The competing claims thus were founded on conquest on the one hand, and ancestry and occupation on the other. Ngamunangapaoa Karaka said explicitly that he grounded his claim on his ancestors; implicit in his evidence also is permanently maintained occupation. After the conquest, as he explained, Moriori did their best to maintain separate cultivations but were not allowed to. Evidence of cultivation was used routinely in the Native Land Court to demonstrate rightful possession.

\section{The Court's Judgments}

In terms of the various blocks before the Court in 1870, Kekerione (also known as Mangatu Karewa) was the subject of a full judgment (see below) and was allocated to Ngati Mutunga on the basis of conquest but Moriori were allocated a 600-acre inalienable reserve. Te Matarae, also the subject of a judgment (below), was disputed by two distinct Ngati Mutunga claims, Te Rakataau on the one hand and Apitia Punga on the other. Te Rakataau's claim received Moriori support from Ngamunangapaoa Karaka and Te Rakataau's case was successful. The Court directed that the names of Moriori people living at a settlement within the block should be included in the order of Court as the owners. In the case of Te Awapatiki block the Ngati Mutunga claim led by Hamuera Koteriki was successful, but Moriori were allocated a reserve of 2000 acres at Owenga. Otonga, a large block of 40,307 acres, included a large number of lakes and was the site of a substantial Moriori settlement. The claimant was Ihakara Ngapuke of Ngati Mutunga who claimed through his parents. This case was adjourned by the Court to the following day, ${ }^{76}$ at which point the Court made a a

75 (1870) 1 Chatham Is MB 20.

76 (1870) 1 Chatham Is MB 44. 
consent order awarding the block to Ngati Mutunga with a 600 -acre Moriori reserve. ${ }^{77}$ There was no judgment for this block, which was regarded by the Court as uncontested. Wharekauri block was similarly uncontested and was also the subject of a consent order, by which eleven Moriori living on this block were allocated an area of 600 acres at Tuaroa; otherwise the block was allocated to the Ngati Mutunga claimants. ${ }^{78}$ A claim to a small island named Rangatira was dismissed for lack of a survey. ${ }^{79}$ In the case of Rangiauria or Pitt Island, the positions were reversed: the claimants were Moriori, who sought a reserve on the island, and the counterclaimants were a section of Ngati Mutunga led by Wiremu Wharepa. Toenga Te Poki, a chief of Ngati Mutunga, spoke also and opposed the Moriori claim strongly, who stated that "[t]he Morioris did not occupy or cultivate on this Island at any time". ${ }^{80}$ The minute book records: ${ }^{81}$

The Court made a Proclamation to the Moriori People to the effect that their claims to this (Pitts [sic])

Island are dismissed and the Court did not feel justified in making a Reserve for Hirawanu as applied for

by him.

The main judgment, that for Kekerione, awarded by far the greater part of the block to Ngati Mutunga on the basis of conquest and settlement. The net effect of the cases has been tabulated by the Waitangi Tribunal as follows (to which must be added Rangiauria, to which the Moriori claims were wholly disallowed): ${ }^{82}$

\begin{tabular}{|l|l|l|l|l|}
\hline Block & Māori acreage & Moriori acreage & Moriori on title & Moriori on block \\
\hline Kekerione & 39,200 & 600 & 2 & $10-20$ \\
\hline Te Matarae & 6,400 & 200 & 2 & About 40 \\
\hline Otonga & 39,657 & $\begin{array}{l}\text { (a) } 600 \\
\text { (b) } 50\end{array}$ & $\begin{array}{l}\text { (a) } 9 \\
\text { (b) } 6\end{array}$ & About 10 \\
\hline Te Awapatiki & 30,876 & 2,000 & 3 & About 10 \\
\hline Wharekauri & 55,055 & (a) 600 & (a) 5 & About 11 men \\
& & (b) 50 & (b) 1 & \\
\hline
\end{tabular}

77 (1870) 1 Chatham Is MB 59.

78 (1870) 1 Chatham Is MB 48.

79 (1870) 1 Chatham Is MB 50.

80 (1870) 1 Chatham Is MB 55.

81 Ibid.

82 Waitangi Tribunal Rekohu, above n 2, at 130. 
What were the effects of the decisions? Dr Gilling has cited a letter from Chief Judge Fenton, sent to the Native Minister, Donald McLean, where Fenton advises that the Chathams cases had gone off "very satisfactorily": 83 "The Taranaki people told me they were well pleased and so were the Moriori."

Gilling finds the remark that Moriori were "well pleased" with the 1870 decisions difficult to credit. What did Moriori have to be pleased about? Fenton's remark in the circumstances is "extraordinary" and "really makes little sense". ${ }^{84}$ Maybe so. On the other hand there was a degree of Ngati Mutunga-Moriori cooperation it at least some of the 1870 hearings. Moriori did receive clear titles to a number of reserve areas in the places where their main settlements and cultivations were located, although admittedly perhaps not all. Perhaps they were reasonably satisfied with the outcome, or at least it seemed better than nothing. Nevertheless, it is the case that overwhelmingly title to the islands was allocated to the newcomers who went to the islands in 1835 and not to the descendants of those who had lived in the islands for half a millennium and built a unique culture there. It took a long and difficult struggle for Moriori to get title to the reserves promised in 1870 and there were disputes over surveys and the reserve boundaries. ${ }^{85}$ While there seems to have been no immediate Moriori protest about the decisions, a protest campaign began around 1878 seemingly in association with Ngai Tahu, themselves confined to small reserve areas in the South Island. A number of Moriori people left the islands and moved to Canterbury where they intermarried with Ngai Tahu people there - in fact many people of Moriori descent today derive from these mixed Moriori-Ngai Tahu communities in the South Island.

Today the Moriori people are undergoing an intense political and cultural resurgence. This resurgence has been triumphantly displayed architecturally, with the building of the new Moriori cultural centre on the Chathams, built at a cost of $\$ 4$ million and opened in 2005 in a moving opening ceremony at which the Prime Minister, Helen Clark, and the Māori Queen, Dame Te Atairangikaahu, were present. ${ }^{86}$ The Moriori place in New Zealand's complicated political and cultural formation is now secure. ${ }^{87}$ Steps are now being taken to resuscitate the Moriori language, which is an Eastern Polynesian language related to New Zealand Māori and the languages of the Cook Islands, Tahiti and the Marquesas, but which has its own distinctive features. About a thousand people today regard themselves as being of Moriori descent.

83 Fenton to McLean, undated, MS 32/267, Alexander Turnbull Library Wellington, cited Gilling, Native Land Court in the Chatham Islands, above n 55, 94.

84 Ibid, 95.

85 See Waitangi Tribunal Rekohu, above n 2, at 154-55.

86 The author with his family visited the Chathams earlier this year (2010) and were privileged to be shown around the new centre by Maui Solomon, lawyer and leader of the Moriori community today.

87 See Waitangi Tribunal Rekohu, above n 2, at 32. 


\section{CONCLUSIONS}

The Chatham Islands cases have been seen by historians as a great injustice to the Moriori people, given the small allocations made to them, and this seems to be a conclusion hard to dispute. However the Court did at least accord to Moriori small reserve areas where their titles would be secure, and there is in fact some contemporary evidence that Moriori were not entirely dissatisfied with the outcome, although historians are wary about accepting this at face value. A contextualised understanding of the cases, focusing on the reasons for apparent Ngati Mutunga intransigence, does in my view lead to a gain in understanding. Ngati Mutunga lost nearly all their ancestral lands in Taranaki, themselves falling victim to the 1840 rule in the Compensation Court. Furtherrmore it is very clear that the famous programme of passive resistance to the Crown in Taranaki centred on the community at Parihaka was greatly dependent on Ngati Mutunga in the Chathams providing gifts of food and money. Ngati Mutunga was not in position to relinquish valuable interests in the Chatham Island that the Native Land Court was willing to recognise and enforce. The broader point here is that an understanding of context is vital to any understanding of the decisions of the Native Land Court. No doubt an understanding of context yields important gains for the understanding of any judicial text, or indeed any document or literary work come to that, but my argument is that is particularly true of the judgments of a body such as the Native Land Court. It operated in highly politicised contexts, but these contexts are seldom apparent from the standardised records in the minute books. The point of collecting together and editing the judgments of the Court would not be a naively positivistic one of assembling a body of material from which one could construct a grand narrative of the evolution of the Court's jurisprudence by means of case analysis, but rather to understand better the importance of the Court as an institution and to make available important primary sources for New Zealand's nineteenth-century history. That, of necessity, involves close attention to the circumstances surrounding the decisions, including the events that led up to them and their aftermath. Whether the Court ever did create an elaborate body of doctrine, apart from some basic nostrums such as the 1840 rule, is actually not at all clear. Mostly the decisions were about the facts, or have a lot to say about traditional history. Discussion of points of law or the conceptualisation of Māori custom are hard to find.

While sometimes the activities of the Native Land Court were of significance to the government this was not the case with the Chatham Islands. To see the Native Land Court as a judicial front for "the Crown" makes no sense in the Chathams. Evidence of direct government interest in the affairs of the Chatham Islands is hard to find. It bought no land there. The Chathams were a remote and neglected place, beyond the gaze of officials. The government had no policies about the Chathams and essentially ignored the islands. Even the Native Land Court went there seldom. There was just one brief exception to this general uninterest and neglect. The islands were so remote and valueless that they were used briefly as a penal colony by the Hawke's Bay provincial government from 186668. The islands' brief history as a penal colony, however, came to an end when the East Coast Māori prisoners, led by Te Kooti, all escaped in 1868. While the activities of Te Whiti and his supporters called forth a coercive response from the colonial state in Taranaki, in the Chathams the "Te Whiti- 
ites" were left alone. Indeed the impression that one gains from Sheila Natusch's account of the Chatham Islands German missionary families was that the islands were a remote and somewhat lackadaisical place where many eccentric personalities from all around the world ended up - from China, New Caledonia, Germany and the Australian penal settlements - and where they lived somewhat hard outdoor lives more as less as they liked. ${ }^{88}$

This article has also drawn attention to the general historiography of the Native Land Court and to the textual status of the Court's decisions. As noted above, this article is the first occasion on which the full texts of the 1870 judgments have appeared in print. Until now, while there has been a great deal published about the history of the Chathams, the 1870 decisions were available only to those who felt inclined to transcribe them themselves from the minute books. The same is true of such pivotal decisions of the Native Land Court as the Rohe Potae case of 1886, Tauponuiatia (also 1886 - which includes the Court's decisions on the famous "gifts of the peaks' which were the foundation of Tongariro National Park), the Waimarino decision of 1886 (which dealt with a vast region of the upper Whanganui), or the Omahu and Omahu rehearings of 1890 and 1892 (important decisions in Hawke's Bay which had close links with litigation over the will of the chief Renata Kawepo, litigation which went in the end to the Privy Council). The fact that these judgments are not in print and difficult to access is surprising and reflects poorly on our national system of law reporting.

88 Sheila Natusch Hell and high water: a German occupation of the Chatham Islands, 1843-1910 (Pegasus, Christchurch, 1977). 


\section{APPENDIX: THE CHATHAM ISLANDS DECISIONS OF 1870}

\section{(1870) 1 Chatham Islands MB 63-67 [Kekerione, Te Matarae and Te Awapatiki Blocks]}

Area: Whole of Chatham Island (Rekohu/Wharekauri) (234,000 acres) and Pitt Island (Rangiauria) Islands (15,000 acres).

Court: Native Land Court, Waitangi, Chatham Island

The Court: Judge Rogan, Charles Wirikake Assessor

Type of case: Investigation of Title

Date of Judgment: Judgment 23 June 1870

Iwi involved in the cases: Kekerewai, Moriori, Ngati Mutunga

Ngati Mutunga, main claimants

Principal legislation: Native Lands Act 1865

$[63 .]^{89} 1^{\text {st }}$ Claim Kekerione Block

In the claim of Wiremu Naera Pomare and others of the Ngatimutunga Tribe to a Block of land called "Kekerione" including the Waitangi District situate in the Chatham Islands.

The evidence of Wi Naera Pomare, Toenga te [Poki?] and Te Rakataau and others which was given before this Court and of the witnesses produced by them is to the following effect that is to say.

In the year 1836 a number of New Zealanders ${ }^{90}$ arrived at a place called Wangaroa ${ }^{91}$ in the Chatham Islands and took possession of Wharekauri capturing the original inhabitants and reducing them to a state of subjection and killing those who attempted to escape to the bush. The claimants simply urge their right to this land by conquest [and] permanent and undisturbed occupation from that period up to the present time.

The opposing claimant Karaka Ngamunangaparoa and others of the Moriori who are descendants of the original inhabitants of these Islands assert their rights to this land from their forefathers who came here from Hawaiki.

In the evidence of Karaka and other witnesses produced by him they admit that the New Zealanders came here in 1836 and took possession of the Island and reduced them to a state of slavery and it was not until Christianity was introduced that they relaxed their severity towards them. In the year

89 Pagination in minutes.

90 That is Māori.

91 Sic: (Whangaroa). 
1859 the New Zealanders agreed with Europeans [64.] to Lease certain lands in the Chatham Islands for sheep and cattle runs [and] they the Moriori were consulted as to the Leasing of the lands but they did not offer any opposition expecting to participate in the advantages derived therefrom. It appears that the New Zealanders did not allow the Morioris to participate in the rents when they were received and in consequence they separated themselves from their masters from that Period up to the present time and now come before the Native Land Court requesting that the whole of the Island should be given up to them.

The Court having fully and carefully considered the evidence given in this claim is of opinion that Wi Naera Pomare and his coclaimants have clearly shown that the original inhabitants of these Islands were conquered by them and the lands were taken possession of by force of arms and the Moriori People were made subject to their rule and also that they maintained their conquest by actual occupation without having subsequently given up any part of the estate to the original owners they (the New Zealanders) only having given sufficient land to the Morioris to cultivate for their support.

The Court therefore is of opinion that Wi Naera Pomare and the Ngatimutunga Tribe are the rightful owners of this Block according to Native custom. But the Court is of opinion that as the original inhabitants have had a permissive right hitherto of cultivating certain portions of land for their maintenance an order will be made in favour of Te Wetini and others of the Moriori People for a Block of land including the settlement of [65.] Rangatira and the Red Bluff containing not less than 600 acres situate within the Kekerione Block, which will be made inalienable.

(signed) John Rogan

Presiding Judge

Waitangi $23^{\text {rd }}$ June 1870

No 2

\section{Matarae Block}

In the claim of Te Rakataau and others of the Kekerewai and Ngatimutunga Tribes to a Block of land called "Matarae" situate in the Chatham Islands.

The evidence of Te Rakataau, Pamaraki, Epiha and Karaka (a Moriori) which was given before this Court is to the following effect that is to say:

In the year 1836 the claimant came from New Zealand and took possession of the Block of land included in this claim and held undisputed possession and occupation.

In the year 1859 the claimant went to New Zealand leaving Pamariki, and Roihi (his sister) in charge and occupation. 
In the year 1863 Te Rakataau returned to the Chatham Island and then Pamariki and Roihi delivered over possession to him. He afterwards caused a survey of the block to be made. The claimant denies that the opposing claimants (Apitia Punga) ever cultivated on the land and declared that he does not know him in connection therewith.

The evidence of Pamariki, Epiha and Karaka (a Moriori) substantiates that of Te Rakataau.

[66.] The principal opposing claimant Apitia Punga asserts his right to a certain portion of this block through his father also that he cultivated on the banks of the [Iwa?] Inanga Stream and that he resided at Te Thu with his Parents also that his cultivations and houses are now on the block in question. He states that he was absent in New Zealand when the survey was made [and] when he returned to Wharekauri he pulled up the Survey Pegs. Te Rakataau put them up again afterwards [and] he (Apitia Punga) got the surveyor to take the bearings of the land he claims and had a plan prepared.

Hamuera Koteriki, Toenga and Ngahiwi (a female) corroborates [sic] the evidence given by the opposing claimant Apitia Punga.

The evidence given by the persons interested in this case is so contradictory that it is difficult to arise at a conclusion as to the real owners. For instance the claimant admits Te Karaka (a Moriori) and Heta Namu (a half Caste Moriori) as claimants in this Block as it appears to him convenient to do so although the Moriori People are ignored generally as the owners of the land in this Island. And [as] there is a Moriori Settlement within this Block their names will be included with Te Rakataau and others in the order of Court as the owners of this land.

It does not appear necessary to refer to Hamuera Koteriki's claim as Te Rakataau has admitted him.

With respect to the counterclaim made by Apitia Punga and Ngahiwi. The Court is of opinion that Apitia Punga has failed to prove his title to the portion of land in the sketch map produced [67.] in Court but having produced evidence that he had cultivated and erected houses on the boundary of this Block near to the River [Iwa?] Inanga he and Ngahiwi are admitted as owners of this land.

\section{J. Rogan}

Judge N.L.C.

Court Waitangi

$23^{\text {rd }}$ June 1870

Claim No 3

\section{Awapatiki Block}


In the claim of Hamuera Koteriki and others to the Block of land called Te Awapatiki. The New Zealanders and Morioris having no further evidence to produce in support of their claims to this land beyond that of Kekerione.

The decision of the Court is that Hamuera Koteriki and the other claimants of the Ngatimutunga Tribe are the rightful owners of this Block of land. But it having been acknowledged that a permanent Moriori settlement is situated within the Block an order for a Reserve of 2000 acres at or near Ouenga ${ }^{92}$ will be made in favour of Torea, Hirawanu Tapu, Karaka Ngamunangapaoa and others for their use and occupation which will be made inalienable.

(sigd) J. Rogan

Judge N.L.C.

Court Waitangi

$23^{\text {rd }}$ June 1870

92 Sic; today usually spelled "Owenga", today also the name of a small fishing port on the eastern coast of Chatham Island. 